\title{
Reseña
}

\section{El prejuicio racial como sentido de posición grupal, de Herbert Blumer.}

\section{Ignacio Prieto Bahamondez ${ }^{1}$}

Herbert Blumer fue un sociólogo estadounidense, conocido como uno de los principales representantes del interaccionismo simbólico, corriente metodológica nacida en la Escuela de Sociología de Chicago, que busca comprender el significado de las interacciones humanas desde la propia comprensión del significado de la acción por parte de los actores. El enfoque de esta escuela radica precisamente en aquello que aparece hoy como sentido común, esto es, la noción de que el significado es una estimación relativa de aquel campo de relaciones que conocemos como "sociedad" y que cada uno lleva consigo.

El texto de la reseña se titula El prejuicio racial como sentido de posición grupal (Race prejudice as a sense of group position), publicado en el primer número de The Pacific Sociological Review (1958), la revista de la asociación profesional de sociólogos de la región pacífica de Estados Unidos. En este breve artículo, Blumer propone un desafío al enfoque predominante en la academia respecto del prejuicio racial. El autor argumenta que la manera más pertinente de trabajar sobre la comprensión del prejuicio racial no radica en la observación de los sentimientos de una persona hacia otra, sino antes en la exploración de cómo un grupo racial se define a sí mismo. Es por tanto la identificación del individuo con un cierto grupo racial el principal fenómeno que explicaría su forma de relacionarse con el integrante de otro grupo racial; por ende,

Sociólogo, Universidad de Concepción, Chile. Contacto: ignacioprieto87@gmail.com 
el prejuicio racial sería una consecuencia de la conformación de grupos con características particulares.

Blumer estima que existen cuatro sentimientos básicos en la constitución del prejuicio racial y que es la conjunción de estos cuatro la que constituye al mismo. Estos sentimientos son la superioridad de la propia raza, la caracterización de la otra raza como extraña, el reclamo de espacios de poder exclusivos y la amenaza de pérdida de este espacio exclusivo. Esto lleva a Blumer a concluir que no es el grupo racial en sí lo que perturba al grupo dominante sino la sensación de que este grupo accede a mayor cantidad de espacios de poder y, por tanto, amenaza el lugar que el grupo dominante estima como propio por derecho.

El prejuicio racial trasciende los sentimientos individuales de una persona hacia otra. No importa si sentimos antipatía, hostilidad u odio, o bien si el encuentro con otro grupo racial nos suscita sentimientos de empatía, compasión o curiosidad; la cuestión que subraya el autor es que estos sentimientos, que pueden cubrir un amplio espectro, tienen los límites fijados por la pertenencia del individuo al grupo dominante ${ }^{2}$. El individuo del grupo racial dominante podrá ir en contra o a favor de los sentimientos del grupo racial dominante, lo que puede suscitar conflictos al interior del mismo, si el grupo se encuentra cohesionado, o bien no surgir problemas cuando el grupo carece de cohesión. Esta cohesión es la que busca profundizar el prejuicio racial, toda vez que es una defensa del espacio que el grupo dominante reclama para sí. Blumer dice que el prejuicio racial funciona a modo de un dispositivo de defensa. "Funciona, si bien de manera cortoplacista, para preservar la integridad y posición del grupo dominante". Esto es extensivo también a la categoría de estatus social, puesto que el individuo de bajo estatus del grupo dominante, una vez

\footnotetext{
Este punto nos es complejo en lo personal ya que no nos permite acceder a un lugar de privilegio desde el cual solamente observar cómo se desenvuelve el prejuicio racial. Este punto nos indica que toda posición respecto a un "otro" es producto de la posición del grupo racial dominante frente al mismo.
} 
confrontado a un individuo del grupo subordinado, se identificará con el individuo de mayor estatus de su mismo grupo racial.

El proceso de definición del grupo subordinado posee dos aspectos claves. Primero, ocurre en medio de una compleja interacción entre los miembros del grupo dominante, compuesto por líderes de opinión, portavoces de distintas agrupaciones, público general, mediante la expresión de sentimientos a través de noticias, rumores, escándalos, entre otros canales de comunicación. "En esta comúnmente vasta y compleja interacción las visiones separadas se enfrentan frente a frente, se influencian, se modifican, se incitan y funden en nuevas formas. De manera correspondiente, los sentimientos expresados se encuentran, se estimulan entre sí, se alimentan mutuamente, se intensifican y emergen nuevos patrones". A través de este proceso se forma la imagen de ambos grupos: el grupo dominante y el grupo subordinado. El segundo aspecto se refiere a que la imagen del grupo subordinado es una imagen abstracta, a la que se atribuyen características como un todo. Si bien los contactos con una persona del grupo subordinado son individuales, la imagen que surge de ello es siempre colectiva, trasciende al individuo en un todo quizá más difuso, pero que el grupo subordinado comparte.

Blumer estima que existen cuatro implicancias producto de esta forma abstracta de ver al grupo subordinado: esta definición se ubica no en lo cercano sino en el área de lo remoto. No refiere al contacto concreto con individuos particulares, sino a la imagen colectiva del grupo. Esto quiere decir que debemos buscar esta imagen en aquellos procesos donde el grupo dominante caracteriza al grupo subordinado, por ejemplo en la prensa; esta caracterización se centra en eventos cruciales que, por su misma fuerza, parecen indicar las facetas que componen al grupo subordinado y que en sus aspectos negativos, por ejemplo, indican la importancia de subrayar la condición de amenaza que el grupo subordinado trae consigo; la mayor influencia en la discusión pública es ejercida por individuos reconocidos por su liderazgo, carisma y/o prestigio. Son los líderes o portavoces de determi- 
nadas opiniones aquellos que inciden de manera significativa en la formación de la imagen del grupo subordinado, es decir, se debe buscar este proceso en este espacio, no en la multiplicidad de experiencias que surgen en el contacto diario; y, es necesario buscar en la conformación de fuertes grupos de interés cómo se movilizan determinadas imágenes de los grupos subordinados. Estas imágenes pueden facultarlos a mantener ciertas ventajas o incluso a adquirir más.

Blumer concluye con dos observaciones sobre la relación entre la posición grupal y el prejuicio racial:

1) El prejuicio racial se arraiga en una sociedad mientras ésta base su funcionamiento en la posición social de los actores. Por ejemplo, en el Sur de Estados Unidos el prejuicio racial es parte constitutiva de las relaciones entre los diferentes, grupos dado que es una sociedad que se sostiene sobre la base de relaciones marcadas por la desigualdad de estatus, cuestión que se reproduce en las diferencias raciales. En otros lugares, donde esta desigualdad no es tan acusada, el prejuicio racial es más débil e intermitente.

2) El sentido de posición grupal y el prejuicio disminuyen cuando el proceso de definiciones no se mantiene al día con los cambios que acaecen en la sociedad. Entonces, cuando no existen grandes eventos, o cuando el grupo dominante defiende la armonía racial, o cuando no existen agentes que persigan determinadas agendas en torno a exacerbar el prejuicio racial, este sentimiento disminuirá.

¿Qué cuestiones suscita la lectura del presente artículo? A mi parecer, son dos las posibilidades que surgen de su lectura para el análisis en ciencias sociales:

1) | En primer lugar, releva la importancia de la posición del grupo para analizar el fenómeno del prejuicio racial, lo que hace visible nuestra propia ubicación como individuos miembros de una agrupación en el escenario social, trascendiendo nuestra trayectoria particular e insertándola en un espacio 
en donde, seamos grupo dominante o subordinado, "aparecemos" como tales en el espacio público. Este punto es notable en tanto cuestiona la idea de que el prejuicio racial resulta de sentimientos impuros y/o injustos de un individuo hacia otro, toda vez que tal prejuicio se constituye sobre la base de la propia identificación de un grupo como aquel grupo de personas que la definición del grupo propio deja afuera.

2) | Dado el actual escenario de Chile, en el cual la inmigración ha crecido sensiblemente durante los últimos años, estudiar estos contactos nos permite ahondar en un fenómeno que hasta el momento ha sido estudiado principalmente en la relación entre "chilenos" y "mapuche". El presente artículo nos entrega pistas acerca de cómo abordar el fenómeno del contacto con el "otro" por medio de la identificación de las características grupales que le asignamos a la categoría "chileno/a", y luego, mediante las imágenes que construimos de las diferentes categorías de inmigrantes que reconocemos en nuestro cotidiano.

\section{Referencias}

Blumer, H. (1958). Race Prejudice as a Sense of Group Position. The Pacific Sociological Review, 1(1), 3-7. 